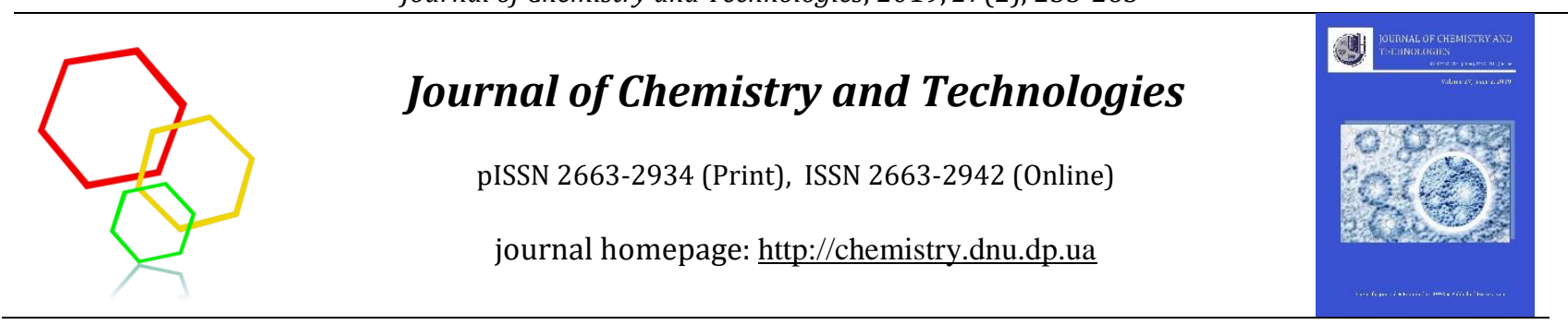

UDC 661.665.1.663.584.6

A STUDY OF LIGNIN-FREE RICE HUSK DECOMPOSITION KINETICS

Tatyana V. Hrydnieva*, Yuri E. Sknar, Pavel V. Riabik, Anna O. Liashenko, Oksana V. Demchyshyna Ukrainian State University of Chemical Technology, Dnipro, Ukraine

Received 3 September 2019; accepted 1 December 2019; available online 21 December 2020

\title{
Abstract
}

The study addresses the problem of using recycled materials for the production of a wide range of diverse products; in this context, the paper investigates the extraction of amorphous silicon (IV) dioxide from rice waste, i.e. rice husk, which differs in its chemical composition from all other cereal crops by a high content of silicon dioxide. Amorphous silicon (IV) oxide is widely used in electronics, medicine, food industry, cosmetology, paintwork materials manufacturing, and other industries. Amorphous silicon(IV) oxide has to meet various requirements, the main ones being amorphous structure, degree of purification, and particle size. A derivatographic method of analysis is used to study the non-isothermal kinetics of rice husk residue thermal decomposition. According to the results of derivatographic, chemical, and phase analyzes, a method for amorphous silicon (IV) oxide extraction by thermal decomposition of rice husk after the lignin removal has been proposed. The values of relative activation energies and the pre-exponential factors of the reactions have been calculated. A mathematical model characterized by a system consisting of three first order differential equations and four algebraic equations has been designed. Through the use of the proposed model, the time response characteristics of the process have been studied.

Keywords: kinetics, rice husk; mechanism; lignin; decomposition; silicon dioxide

\section{ДОСЛІДЖЕННЯ КІНЕТИКИ ТЕРМІЧНОГО РОЗКЛАДАННЯ РИСОВОГО ЛУШПИННЯ ПІСЛЯ ВИДАЛЕННЯ ЛІГНІНУ}

Тетяна В. Гриднєва, Юрій Є. Скнар, Павло В. Рябік, Анна О. Ляшенко, Оксана В. Демчишина ДВНЗ «Український хіміко-технологічний університет»

\section{Анотація}

У рамках вирішення проблеми використання вторинної сировини для виробництва широкого спектру різноманітних продуктів, розглядається виділення аморфного силіцій (IV) оксиду з відходів рисового виробництва - рисового лушпиння, яке відрізняється за своїм хімічним складом від усіх інших злакових культур великим вмістом діоксиду кремнію. Аморфний силіцій (IV) оксид має широкий спектр застосування в електроніці, медицині, харчовій промисловості, косметології, при виробництві лаків і фарб, а також в інших галузях промисловості. До аморфного діоксиду кремнію пред'являються різні вимоги, але основними є аморфна структура, ступінь очищення та розмір частинок. Для вивчення неізотермічної кінетики термічного розкладання залишку рисового лушпиння застосовували дериватографічний метод аналізу. За результатами дериватографічного, хімічного і фазового аналізів запропоновано механізм процесу виділення аморфного силіцій (IV) оксиду шляхом термічного розкладання рисового лушпиння після видалення лігніну. Розраховані значення умовних енергій активації і предекспоненціальних множників реакцій. Побудовано математичну модель, яка описується системою, що складається 3 трьох диференціальних рівнянь першого порядку і чотирьох алгебраїчних. 3 ï̈ допомогою вивчені тимчасові характеристики процесу.

Ключові слова: кінетика; рисове лушпиння; механізм; лігнін; розкладання; силіцій (IV) оксид

- Corresponding author: e-mail address: tasya.gridneva@gmail.com

(C) 2019 Oles Honchar Dnipro National University

doi: $10.15421 / 081926$ 
Journal of Chemistry and Technologies, 2019, 27(2), 255-263

\section{ИССЛЕДОВАНИЕ КИНЕТИКИ ТЕРМИЧЕСКОГО РАЗЛОЖЕНИЯ РИСОВОЙ} ШЕЛУХИ ПОСЛЕ УДАЛЕНИЯ ЛИГНИНА

Татьяна В. Гриднева, Юрий Е. Скнар, Павел В. Рябик, Анна О. Ляшенко, Оксана В. Демчишина

гВУЗ «Украинский химико-технологический университет»

\section{Аннотация}

В рамках решения проблемы использования вторичного сырья для производства широкого спектра разнообразных продуктов, рассматривается выделение аморфного диоксида кремния из отходов рисового производства - рисовой шелухи, которая отличается по своему химическому составу от всех других злаковых культур большим содержанием диоксида кремния. Аморфный диоксид кремния имеет широкий спектр применения в электронике, медицине, пищевой промышленности, косметологии, при производстве лаков и красок, а также в других отраслях промышленности. К аморфному диоксиду кремния предъявляются различные требования, но основными являются аморфная структура, степень очистки и размер частиц. Для изучения неизотермической кинетики термического разложения остатка рисовой шелухи применяли дериватографический метод анализа. По результатам дериватографического, химического и фазового анализов предложен механизм процесса выделения аморфного диоксида кремния путем термического разложения рисовой шелухи после удаления лигнина. Рассчитаны значения условных энергий активации и предэкспоненциальных множителей реакций. Построена математическая модель, которая описывается системой, состоящей из трех дифференциальных уравнений первого порядка и четырех алгебраических. С ее помощью изучены временные характеристики процесса.

Ключевые слова: кинетика, рисовая шелуха, механизм, лигнин, разложение, диоксид кремния

\section{Introduction}

One of the important and urgent problems in Ukraine is the disposal of solid wastes and development of environmentally friendly and low-waste technologies of their recycling [1-3]. Large-tonnage, constantly renewable agricultural wastes, namely rice husk (RH) are of great interest. Rice is the most common crop in the world. Rice is grown in more than 100 countries around the world. World rice production is 530 million tons, which corresponds to 110 million tons of rice husk. The countries with the highest level of rice production are China (140 million tons), India (110 million tons), which makes up almost $60 \%$ of the global volume. They are followed by Thailand, the Philippines, Brazil, Japan, and Vietnam with lower productivity [45]. The total rice production in Ukraine reaches 100 thousand tons/year with 20 thousand tons of rice husk. The use of rice husk allows expanding the raw material resource base, creating an effective, environmentally friendly production for extraction of amorphous silicon(IV) oxide that meets the specified requirements. RH mostly consists of lignin (according to [6-9] 40\% mass), cellulose (according to $36 \%$ mass ) and around $24 \%$ mass of silicon(IV) oxide and metal oxides $[9 ; 10]$. RH can be used as raw material for amorphous silicon(IV) oxide extraction for various purposes. The advantage of this raw material is its yearly reproducibility and possibility to get valuable components with prespecified properties [9; 11-16].

The traditional methods of obtaining silicon(IV) oxide from mineral raw materials are multistage and energy-consuming. The extraction of amorphous silicon(IV) oxide from RH reduces energy consumption, and the resulting product has a purity of $99.9 \%$ of the mass. A number of papers [17-23] include the results of experiments on rice husk chemical processing in various process modes. To obtain high purity amorphous silicon dioxide, it is necessary to extract carbon-containing compounds from rice husk.

Thermodynamic research [8] made it possible to determine the operating parameters of the $\mathrm{RH}$ heat treatment process (temperature, pressure, the composition of the gaseous phase), which allowed reducing the amount of experimental studies and planning them. However, thermodynamic studies do not allow to determine the temporal characteristics of the process. The purpose of this paper is to study the laws of thermal decomposition of rice husks freed from lignin. Determination of the kinetic parameters of this process in non-isothermal conditions, the establishment of the mechanism of the process of thermal decomposition. Compilation of a mathematical model that fully describes this process.

\section{Experimental}

A derivatographic method is used when studying the kinetics of thermal decomposition of rice husks freed from lignin $[24 ; 25]$. This method allows applying a complex procedure of concurrent analysis of mass variation curves (TG), and temperature change (DTA). The derivatographic method in line with other methods of the analysis (chemical, and X-ray phase, etc.) allows determining the chemistry of transformations at samples heating and 
Journal of Chemistry and Technologies, 2019, 27(2), 255-263

calculating the reaction activation energy $\mathrm{E}$ and the pre-exponential factor $k_{0}$. A sample of rice husk was subjected to a derivatographic study, from which lignin was extracted with an alcoholic acid extractant according to the procedure [27]. The composition of the residue after the extraction of lignin and decomposition products during thermal decomposition was determined by size exclusion chromatography using a CHNS / O 2400 Seriesll analyzer. The obtained results are shown in table 1.

The elemental composition and ash content of rice husk freed from lignin

Table 1

\begin{tabular}{c|c|c}
\hline Parameter & $\begin{array}{c}\text { Symbol, } \\
\text { UOM }\end{array}$ & Actual Value \\
\hline Ash content, dry basis & $\mathrm{A}^{\mathrm{d},} \%$ & 31.8 \\
\hline Carbon Mass Content & $\mathrm{C}^{\mathrm{d},} \%$ & 23.52 \\
\hline Hydrogen Mass Content & $\mathrm{H}^{\mathrm{d}}, \%$ & 4.694 \\
\hline Nitrogen Mass Content & $\mathrm{N}^{\mathrm{d}}, \%$ & 0.28 \\
\hline Oxygen Mass Content & $\mathrm{O}^{\mathrm{d}} \mathrm{d}, \%$ & 39.76 \\
\hline
\end{tabular}

Based on the data given in table 1 , a conditional formula of a rice husk molecule, freed from lignin, of the following form was proposed: $\mathrm{C}_{1,96} \mathrm{H}_{4,64} \mathrm{O}_{2,48} \mathrm{~N}_{0,02} \cdot 0.53 \mathrm{SiO}_{2} \cdot 0,30 \mathrm{H}_{2} \mathrm{O}$.

A derivatogram was obtained using a Paulik F.- Paulik J.- Erdey L. system derivatograph in air in the temperature range $20-1000{ }^{\circ} \mathrm{C}$ at a heating rate of $0.17 \mathrm{~K} / \mathrm{s}$. Statistical processing of the obtained results and mathematical modeling were carried out using standard Mathcad 14 software.

\section{Results and discussion}

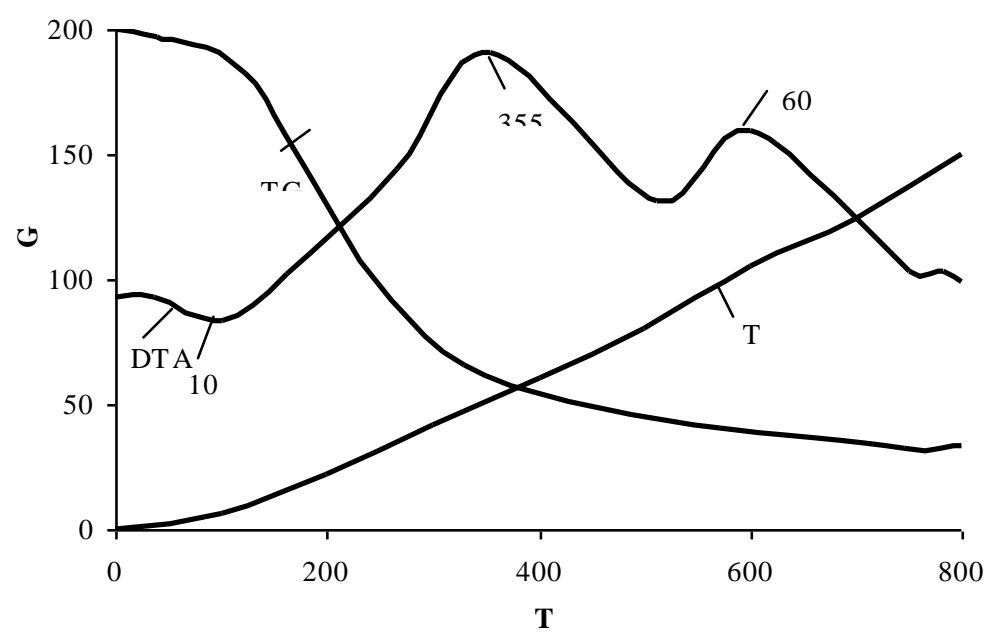

Fig. 1 shows a derivatogram of $\mathrm{RH}$ sample thermal decomposition after the $\mathrm{RH}$ lignin removal in air. As one can see in Fig. 1, three peaks are recorded on the thermal image of the sample. The first endoeffect is observed at $102^{\circ} \mathrm{C}$, and two exoeffects correspond to $355^{\circ} \mathrm{C}$ and $600{ }^{\circ} \mathrm{C}$ respectively. The main organic components of rice husk are cellulose and lignin with burn temperature of $350{ }^{\circ} \mathrm{C}$ and $500{ }^{\circ} \mathrm{C}$ respectively [28-30]. Therefore, we can make a conclusion that the exoeffects on the derivatogram correspond to the burning of cellulose and some lignin remained unextracted from RH.

Fig.1. Derivatogram of the thermal decomposition process of a sample of rice husk freed from lignin in air

At $102{ }^{\circ} \mathrm{C}$ water is evaporated. Based on the change in the sample mass, the conditional initial rice husk molecule freed from lignin, $\mathrm{C}_{1.96} \mathrm{H}_{4.64} \mathrm{O}_{2.48} \mathrm{~N}_{0.02} \cdot 0.53 \mathrm{SiO}_{2} \cdot 0.30 \mathrm{H}_{2} \mathrm{O}$, can be divided into its dehydrated part and water. At $250-530^{\circ} \mathrm{C}$, cellulose thermal oxidative degradation occurs along with formation of product $\mathrm{C}_{0.94} \mathrm{H}_{2.48} \mathrm{O}_{1.88} \cdot 0.53 \mathrm{SiO}_{2}$. Then at $530-730$
${ }^{\circ} \mathrm{C}$, the further thermal degradation of residual carbon-containing components occurs along with silicon(IV) oxide formation. Thus, we can write the following scheme of chemical transformations:

$$
\begin{gathered}
\mathrm{C}_{1.96} \mathrm{H}_{4.64} \mathrm{O}_{2.48} \mathrm{~N}_{2} \cdot 0.53 \mathrm{SiO}_{2} \cdot 0.30 \mathrm{H}_{2} \mathrm{O} \rightarrow \\
\mathrm{C}_{1.96} \mathrm{H}_{4.64} \mathrm{O}_{2.48} \mathrm{~N}_{2} \cdot 0,53 \mathrm{SiO}_{2}+0.30 \mathrm{H}_{2} \mathrm{O}
\end{gathered}
$$


$\mathrm{C}_{1.96} \mathrm{H}_{4.64} \mathrm{O}_{2.48} \mathrm{~N}_{2} \cdot 0.53 \mathrm{SiO}_{2}+1.24 \mathrm{O}_{2} \rightarrow$

$\mathrm{C}_{0.94} \mathrm{H}_{2.48} \mathrm{O}_{1.88} \cdot 0.53 \mathrm{SiO}_{2}+\mathrm{N}_{2}+1.08 \mathrm{H}_{2} \mathrm{O}+1.02 \mathrm{CO}_{2}$

$\mathrm{C}_{0.94} \mathrm{H}_{2.48} \mathrm{O}_{1.88} \cdot 0.53 \mathrm{SiO}_{2}+0.62 \mathrm{O}_{2} \rightarrow$

$0.53 \mathrm{SiO}_{2}+1.24 \mathrm{H}_{2} \mathrm{O}+0.94 \mathrm{CO}_{2}$
According to the proposed scheme of decomposition of rice husk free from lignin, with the release of silicon dioxide during chemical transformations, seven components are involved.

We designate them with symbols, as shown in Table 2.

Table 2

Component Symbols

\begin{tabular}{c|c}
\hline Component & Symbols \\
\hline $\mathrm{C}_{1.96} \mathrm{H}_{4.64 \mathrm{O}_{2.48} \mathrm{~N}_{2} \cdot 0.53 \mathrm{SiO}_{2} \cdot 0.30 \mathrm{H}_{2} \mathrm{O}}$ & $\mathrm{n}_{1}$ \\
\hline $\mathrm{C}_{1.96} \mathrm{H}_{4.64} \mathrm{O}_{2.48} \mathrm{~N}_{2} \cdot 0.53 \mathrm{SiO}_{2}$ & $\mathrm{n}_{2}$ \\
\hline $\mathrm{C}_{0.94} \mathrm{H}_{2.48} \mathrm{O}_{1.88} \cdot 0.53 \mathrm{SiO}_{2}$ & $\mathrm{n}_{3}$ \\
\hline $\mathrm{N}_{2}$ & $\mathrm{n}_{4}$ \\
\hline $\mathrm{H}_{2} \mathrm{O}$ & $\mathrm{n}_{5}$ \\
\hline $\mathrm{CO}_{2}$ & $\mathrm{n}_{6}$ \\
\hline $\mathrm{SiO}_{2}$ & $\mathrm{n}_{7}$ \\
\hline
\end{tabular}

The mathematical model that corresponds to this process consists of three differential kinetic and four algebraic equations of material balance:

$$
\begin{aligned}
& \frac{d n_{1}}{d \tau}=-k_{1} n_{1} \\
& \frac{d n_{2}}{d \tau}=k_{1} n_{1}-k_{2} n_{2} \\
& \frac{d n_{3}}{d \tau}=k_{2} n_{2}-k_{3} n_{3} \\
& n_{4}=0,01 n_{1}^{0}-0,01 n_{1}-0,01 n_{2} \\
& n_{5}=2,62 n_{1}^{0}-2,62 n_{1}-2,32 n_{2}-1,24 n_{3} \\
& n_{6}=1,96 n_{1}^{0}-1,96 n_{1}-1,96 n_{2}-0,94 n_{3} \\
& n_{7}=0,53\left(n_{1}^{0}-n_{1}-n_{2}-n_{3}\right)
\end{aligned}
$$

where $k_{1}-k_{3}-$ are the reaction rate constants (1-3), $\mathrm{s}^{-1}$;

$\tau$ - time, $s$

$\mathrm{n}_{1}{ }^{\circ}-$ the initial number of moles of rice husk freed from lignin;

$n_{1}-n_{7}-$ the current number of moles of the corresponding components.

To determine the kinetic parameters of the $\mathrm{RH}$ thermal decomposition process after the lignin removal, peaks in the thermal image (Fig. 1) that correspond to reactions (1-3) are determined. The reference temperatures are determined by the bend point on the DTG curve and are as follows: $\mathrm{Ts}_{1}=375 \mathrm{~K}, \mathrm{Ts}_{2}=628 \mathrm{~K}, \mathrm{Ts}_{3}=823 \mathrm{~K}$.
Arrhenius equation is used to define the specific reaction rate:

$$
\mathrm{k}=\mathrm{k}_{0} \exp \left(-\frac{\mathrm{E}}{\mathrm{RT}}\right)
$$

where $k$ - specific reaction rate, $\mathrm{c}^{-1}$;

$k_{0}$ - pre-exponential factor, $\mathrm{c}^{-1}$;

$\mathrm{T}$ - varying temperature, $\mathrm{K}$.

Relative activation energy is defined using the following equation:

$$
\mathrm{E}=\operatorname{tg} \beta \cdot \mathrm{RT}_{\mathrm{S}}^{2}
$$

where Ts - reference temperature, $\mathrm{K}$;

$\operatorname{tg} \beta$ - slope of the line made in $W^{*}=f(\Theta)$ coordinates.

Equation [31] is used to plot $\mathrm{W}^{*}=\ln \ell n \frac{\mathrm{W}_{\mathrm{o}}-\mathrm{W}_{\mathrm{k}}}{\mathrm{W}_{\mathrm{o}}-\mathrm{W}_{\tau}}$ against temperature $\Theta$ :

$$
\ln \ell n \frac{\mathrm{W}_{\mathrm{o}}-\mathrm{W}_{\mathrm{k}}}{\mathrm{W}_{\mathrm{o}}-\mathrm{W}_{\tau}}=\frac{\mathrm{E} \cdot \theta}{\mathrm{RT}_{\mathrm{S}}^{2}}
$$

where $\mathrm{W}_{0}, \mathrm{~W} \tau, \mathrm{W}_{\mathrm{\kappa}}$ are the initial, current and final sample mass respectively, g;

$\mathrm{E}$ - relative reaction activation energy, $\mathrm{J} / \mathrm{mol}$;

$\mathrm{R}$ - universal gas constant, $\mathrm{R}=8.310 \mathrm{~J} /(\mathrm{mol} \cdot \mathrm{K})$;

$\theta$ - temperature difference, taken with an arbitrary step on the derivatogram. For calculations, we accept $\theta_{1}= \pm 10 \kappa, \theta_{2}= \pm 20 \kappa$, $\theta_{3}= \pm 30^{\circ} \mathrm{K}$ 


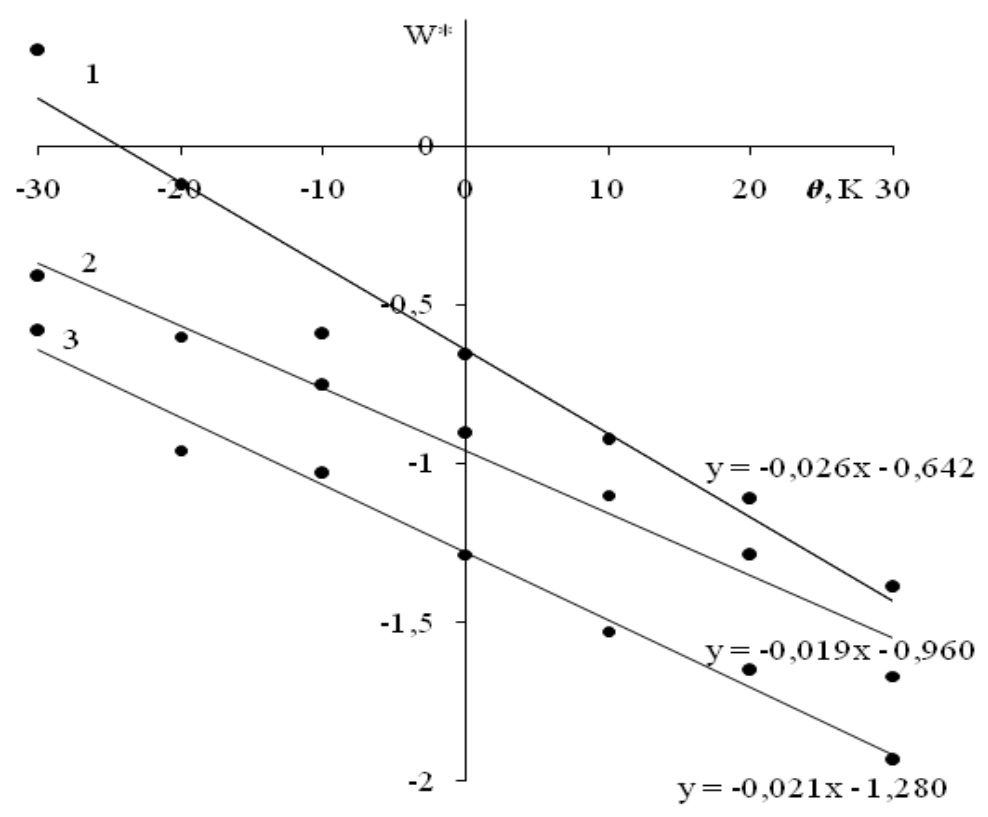

Fig.2. Dependences of $\mathrm{W}^{*}$ on the temperature difference $\theta$ for reactions (1-3): 1 - for reaction (1) at a temperature $T s_{1}=375 K ; 2$ - for reaction (2) at a temperature $T s_{2}=628 \mathrm{~K} ; 3$ - for reaction (3) at a temperature $T s_{3}$ $=823 \mathrm{~K}$.

Equation $[24 ; 31]$ is used to define preexponential factor $k_{0}$ :

$$
\mathrm{k}_{0}=\frac{\mathrm{g} \cdot \mathrm{E}}{\mathrm{RT}_{\mathrm{S}}^{2} \exp \left(-\frac{\mathrm{E}}{\mathrm{RTs}}\right)}
$$

where $\mathrm{g}$ - sample heating rate, $\mathrm{K} / \mathrm{sec}$.

The calculated values of $\mathrm{E}$ and $\mathrm{k}_{0}$ are given in Table 3.

Kinetic parameters of the process of thermal decomposition of lignin-free rice husk

\begin{tabular}{c|c|c|c}
\hline $\begin{array}{c}\text { Chemical } \\
\text { Reaction }\end{array}$ & $\mathrm{T}, \mathrm{K}$ & $\begin{array}{c}\text { Pre-Exponential Factor, k0, } \\
\mathrm{c}-1\end{array}$ & $\begin{array}{c}\text { Relative Reaction } \\
\text { Activation Energy, E, J/mol }\end{array}$ \\
\hline 1 & 375 & $0.69 \cdot 102$ & $30.8 \cdot 103$ \\
\hline 2 & 628 & $1.23 \cdot 104$ & $62.95 \cdot 103$ \\
\hline 3 & 823 & $1.00 \cdot 105$ & $119 \cdot 103$ \\
\hline
\end{tabular}

When solving the system of equations (4-10) using standard Mathcad 14 software, the spatiotemporal properties of the process of thermal decomposition of lignin-free rice husk are determined (Fig. 3).

The proposed mathematical model allows us to calculate the degree of conversion of lignin- free rice husk to silicon (IV) oxide, depending on the temperature of thermal decomposition. The dependence obtained as a result of solving the system of equations (4-10) is shown in Fig. 4 by a solid line. 


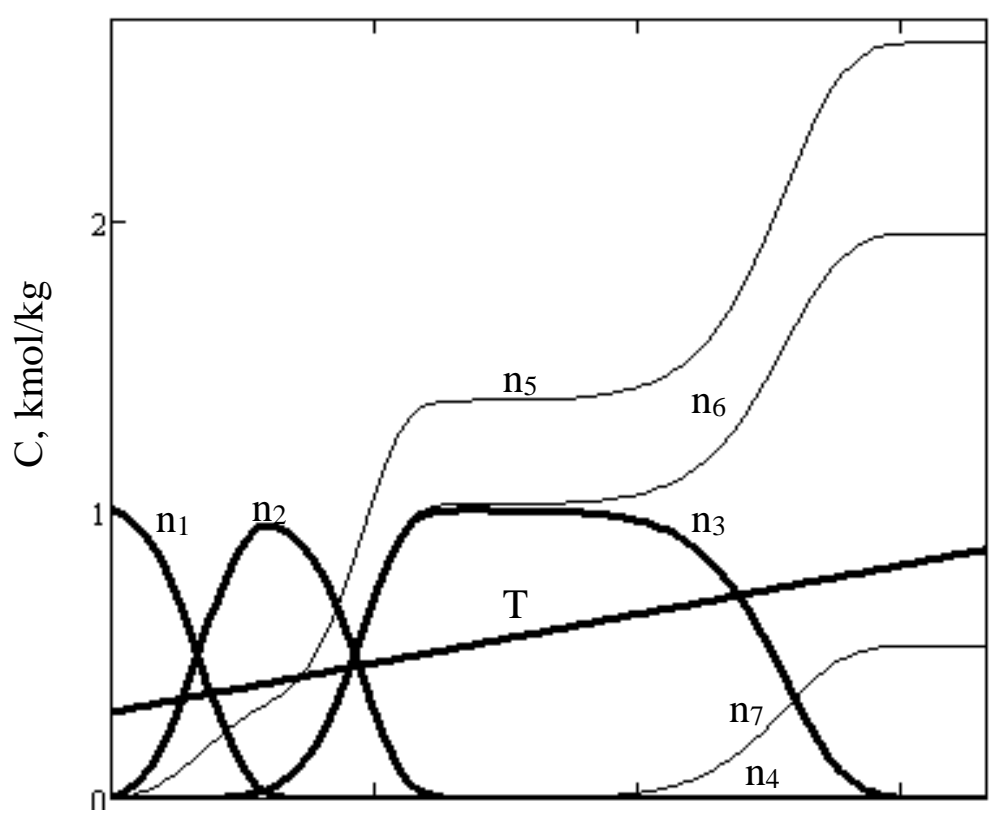

Time, sec

Fig. 3. The ratio of the concentrations of reaction products in the process of thermal decomposition of lignin-free rice husk

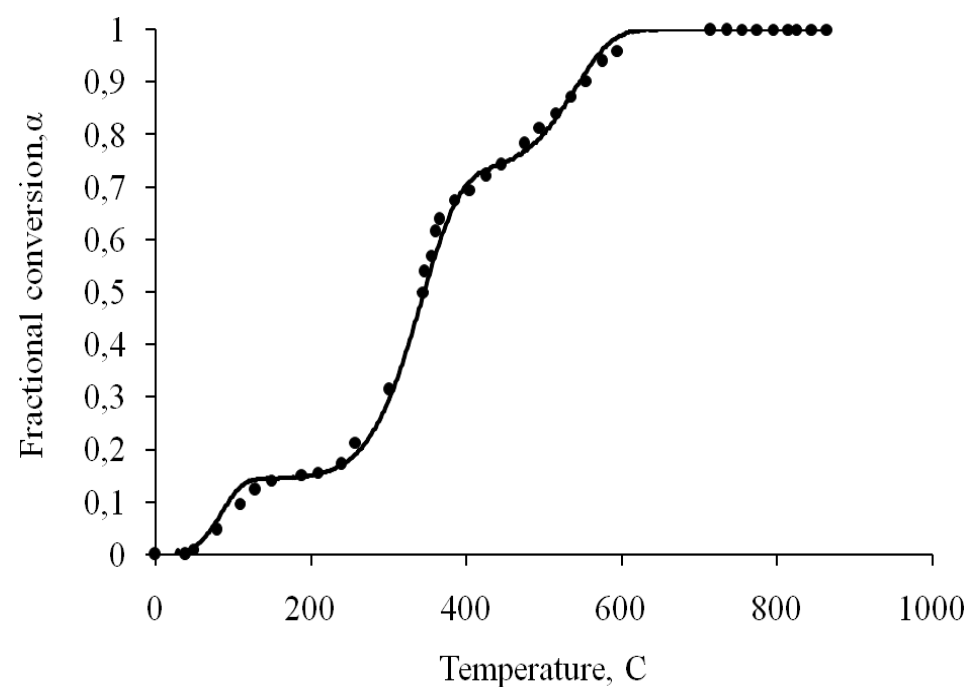

- is the calculated curve;

- experimental values.

Fig. 4. Temperature dependence of the conversion of lignin-free rice husk to silicon(IV) oxide on temperature

The calculation of the degree of conversion on the basis of experimental data was carried out according to the formula:

$$
\alpha=\frac{W_{0}-W_{s}}{W_{0}-W_{K}}
$$

where $\mathrm{W}_{0}$ - is the initial mass of the sample;

$\mathrm{W}_{\mathrm{S}}$ - is the mass of the sample at TS;

$\mathrm{W}_{\mathrm{K}}$ - is the final mass of the sample.
The values of the degree of conversion calculated from the experimental data are shown in Fig. 4 by dots.

The proposed mathematical model allows establishing the dependence of the time of formation of silicon(IV) oxide with a degree of conversion equal to unity on the heating rate of rice husk free of lignin. As can be seen from Fig. 5, the minimum time spent on this process with a degree of conversion equal to unity corresponds 
to a heating rate of $0.6 \mathrm{~K} / \mathrm{s}$. The calculated value is in good agreement with the experimental data.

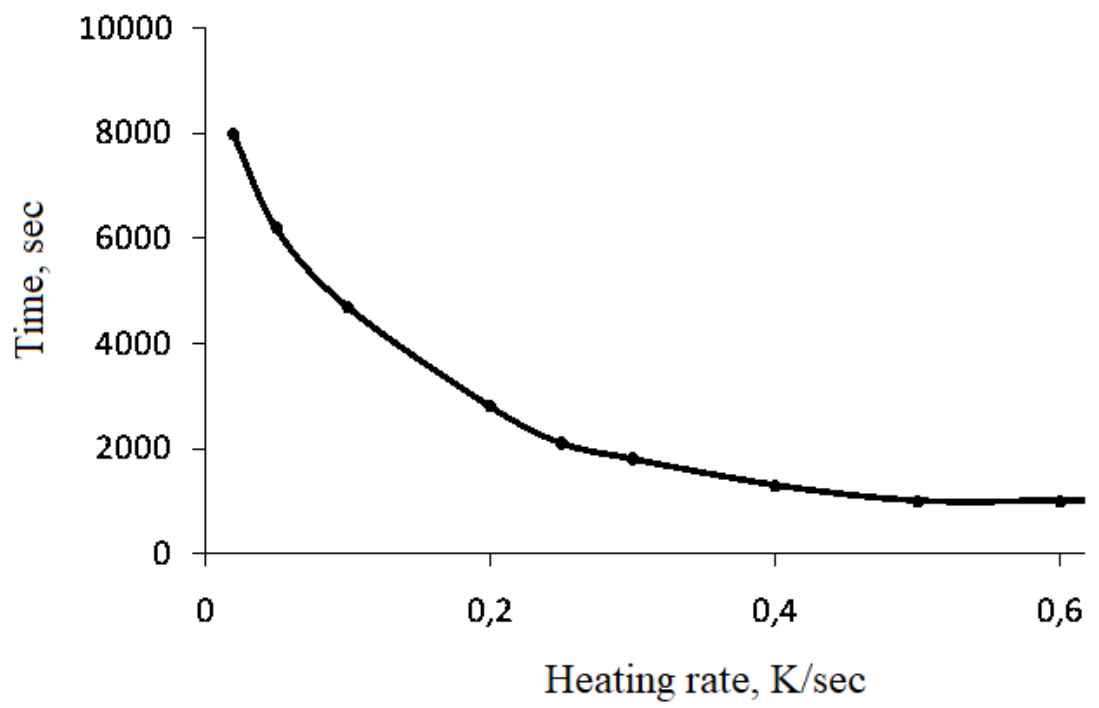

Fig. 5. Dependence of the time for the release of silicon(IV) oxide on the heating rate of a sample of lignin-free rice husk

Consequently, the proposed mathematical model adequately describes the experimental data and can be used in the design of reactors for the processing of lignin-free rice husks in the production of high-purity amorphous silicon(IV) oxide.

\section{Conclusions:}

1. Based on the obtained experimental data on the kinetics of thermal decomposition of ligninfree rice husk, the scheme of this process has been established. It has been shown that the formation of silicon(IV) oxide occurs during successive conversions of the conditional molecules $\quad \mathrm{C}_{1.96} \mathrm{H}_{4.64} \mathrm{O}_{2.48} \mathrm{~N}_{2} \cdot 0.53 \mathrm{SiO}_{2} \cdot 0.30 \mathrm{H}_{2} \mathrm{O}$, $\mathrm{C}_{1.96} \mathrm{H}_{4.64} \mathrm{O}_{2.48} \mathrm{~N}_{2} \cdot 0.53 \mathrm{SiO}_{2}, \mathrm{C}_{0,94} \mathrm{H}_{2,48} \mathrm{O}_{1,88} \cdot 0.53 \mathrm{SiO}_{2}$ at temperatures of 102,355 and $600{ }^{\circ} \mathrm{C}$.

2. A mathematical model for description of the kinetics of the thermal decomposition of ligninfree rice husks has been developed. The kinetic parameters of the process were obtained and an experimental verification of the adequacy of the proposed model was carried out.

3. It has been shown that the formation of silicon (IV) oxide with a degree of conversion equal to unity occurs at a temperature of $600^{\circ} \mathrm{C}$. A minimum process time of 2000 seconds is provided at a heating rate of at least $0.6 \mathrm{~K} / \mathrm{s}$. It is proposed to use the developed mathematical model and the results of experimental studies in the design of reactors for processing lignin-free rice husks in the production of high-purity amorphous silicon(IV) oxide.

\section{Библиографические ссылки}

[1] Госпадинова В. И. Использование вторичного сырья рисового производства / В. И. Госпадинова, Т. Л. Коротенко // Рисоводство. - 2010. - N 17. С. $79-81$.

[2] Дроздник И. Д. Анализ технологических свойств и сырьевой базы альтернативного топлива Украины/ И.Д. Дроздник, Н.И. Борискина, Я. С. Балаева // Углехимический журнал. - 2015. N 1-2. - C. 12-16.

[3] Hura D.V. Integrated process of obtaining heat and silicon(IV) oxide from siliceous plant materials / D. V. Hura, P. I. Soroka, A. A. Cheremysinova // Chemical and materials engineering. - USA. - 2014. V. 2, N 3. - P. 72 - 78.

[4] Food and Agriculture Organization of the United Nations. [Електронний ресурс]. - Режим доступу: http://www.fao.org/faostat/en/\#home.

[5] Nguyen N. V. Meeting the challenges of global rice production/ N. V. Nguyen, · A. Ferrero // Paddy Water Environ. - 2006. - Vol.4. - P. 1-9.

[6] Никитин В. М. Химия древесины и целлюлозы / В. М. Никитин, А. В. Оболенская, В. П. Щеголев. - М.: Лесная промышленность, 1978. -368 с.

[7] Получение аморфного диоксида кремния повышенной чистоты из рисовой шелухи / Т. В. Гриднева, А.В.Кравченко, В. Д. Барский, П. В. Рябик // Вісник НТУ ХПІ. Сер. Хім., хім. технол. - 2016. - N 35 (1207). - С. 55-63.

[8] Определение технологических параметров процесса получения кремнийсодержащих соединений из отходов рисового производства / Т. В Гриднева, А.А Белая, П.И. Сорока, О.А. Тертышный // Збірник наукових праць OHAXT. - 2011. - N 39/2. - C. 33-36.

[9] Obtaining of high purity amorphous silicon dioxide from rice husk / T. V. Gridneva A. V. Kravchenko, V. D. Barsky, N. A. Gurevina // Chemistry\&Chemical Technology. - 2016. - Vol. 10, N 4. - Р. 499-505.

[10] Гордиенко М. А. О выходе продуктов газификации твердого углеродсодержащего сырья / 
Journal of Chemistry and Technologies, 2019, 27(2), 255-263

А. М. Гордиенко // Углехимический журнал. - 2015. - N 1-2. - C.21-25.

[11] Characterization of silica produced from rice husk ash: Comparison of purification and processing methods/ I. J. Fernandes, D. Calheiro, Felipe A. L. Sanches [et al.] //Mater. Resear. - 2017. - Vol.20, N 2. - P. 512-518.

[12] The use of the heat-treated rise husk as elastomeric compositions fillers / O. A. Tertyshnyi, V. I. Ovcharov, K. M. Sukhyy, L. A. Sokolova, V. L. Kalinyuk // Voprosy Khimii I khimicheskoi Teknologii. - 2018. - Vol. 3. P. 79-89.

[13] Generation of high quality biogenic silica by combustion of rice husk and rice straw combined with pre- and post-treatment strategies-a review/ H.B. Dizaji, T. Zeng, I. Hartmann, D. Enke [et al.] //Apll. Sci. - 2019. - Vol. 9 (1083). - P. 1-27.

[14] Costa J. A. S. Systematic evaluation of amorphous silica production from rice husk ashes / J. A. S. Costa, C. M. Paranhos // J Clean Prod. - 2018. - Vol. 192. - P. 688-697.

[15] Effective and highly recyclable ceramic membrane based on amorphous nanosilica for dye removal from the aqueous solutions/ G.M.K. Tolba, A.M. Bastaweesy, E. A. Ashour [et al.] //Arab. J. Chem. - 2016. - Vol. 9. P. 286-296.

[16] Hossain Sk. S. Rice husk/rice husk ash as an alternative source of silica in ceramics: A review / Sk. S. Hossain, L. Mathur, P. K. Roy// J. As. Cer. S. - 2018. - Vol. 6, N4. P. 299-313.

[17] Kalapathy U. A simple method for production of pure silica from rice hull ash/ U. Kalapathy, A. Proctor, J.Shultz// Bioresource Tech. - 2000. - Vol.73. P. 257-262.

[18] Todkar B.S. Extraction of silica from rice husk / B. S. Todkar, On. A. Deorukhkar, Sat. M. Deshmukh // International Journal of Engineering Research and Development. - 2016. - Vol. 12, N3. - P. 69-74.

[19] High-purity nano silica powder from rice husk using a simple chemical method / R. Yuvakkumar, V. Elango, V. Rajendran, N. Kannan // Journal of Experimental Nanoscience. - 2014. - Vol. 20, N3. - P. 272-281.

[20] Liou T.-H. Preparation and characterization of nanostructured silica from rice husk / T.-H. Liou // Materials Science and Engineering. - 2004. - Vol. A364. - P.313-323.

[21] Bakara, R. Abu. Production of high purity amorphous silica from rice husk/ R. Abu. Bakara, R. Yahyaa, S. N. Gana // Procedia Chemistry. - 2016. - Vol.19. P. $189-195$.

[22] Real C. Preparation of silica from rice husks/ C. Real, Maria D. Alcala, Jose M. Criado // J. Am. Ceram. Soc. 1996. - Vol.79, N8. - P. 2012-2016.

[23] $\mathrm{Gu}, \mathrm{S}$. Kinetic study on the preparation of silica from rice husk under various pretreatments/S. Gu, J. Zhou, Z. Luo [et al.] // J Therm Anal Calorim. - 2015. Vol.119. - P. 2159-2169.

[24] Исследование процесса экстракции лигнина спиртовым екстрагентом / Т. В.Гриднева, П. И. Сорока, О.А. Тертышный, Е. С. Смирнова, П. В. Рябик // Вопр. химии и хим. технологии. 2007. - N 6. - С. 212-214.

[25] Уэндланд У. Термические методы анализа / У. Уэндланд.- М.: Мир, 1978.- 526 с.

[26] Zako J. Kinetic Analysis of TG-data. Thermal decomposition of calcium carbonate / J. Zako, H. E. Arzt // Ibid. - 1974.- N6.- P. 651-656.
[27] Исследование кинетики процессов получения кремнийсодержащих соединений из рисовой шелухи / Т. В. Гриднева, А. А. Белая, П. И. Сорока [и др.] // Наукові праці Одеської Нац. академії харчов. технологій. - 2010. - Т.2, N.37 - C.4-8.

[28] Боголицын К.Г. Физическая химия линина : монографія / К.Г.Боголицын, В. В Лунин - М.: Академкнига, 2010.- 489 с.

[29] Neish A. C. Coumarins, phenylpropanes and lignin. Plant biochemistry / J. Bonner and J. E. Varner Eds. New York: Academic Press, 1965. - Chapter 23. - Sec. VI. - $581 \mathrm{p}$.

[30] Sestak J. The studies of heterogeneous processes by thermal analysis / J.Sestak, V. Satavo, W. W. Wendlandt // Thermochim. acta. - 1973.- Vol. 7, N5. - P. 333-356.

[31] Получение ферритовых порошков в потоках высокотемпературных теплоносителей / В. Д. Пархоменко, П. И. Сорока, Л. А. Голубков, П. В. Липатов. - К.: Наук. думка,1988.- 152 с.

\section{References}

[1] Hospadynova, V. Y., Korotenko T. L. (2010). [Using recycled rice]. Rysovodstvo - Rice-growing, (17), 79 -81. (in Russian).

[2] Drozdnik, I.D. Boriskina, N.I., Balaeva J.S. (2015). [Analysis of technological properties and raw material base of alternative fuel of Ukraine]. Uglehimicheskiy zhurnal - The Coal- Chemical Journal., (1-2), 12-16. (in Russian).

[3] Hura, D.V. Soroka, P.I., Cheremysinova, A.A. (2014). Integrated process of obtaining heat and silicon(IV) oxide from siliceous plant materials. Chemical and materials engineering, 2(3), $72-78$.

[4] Food and Agriculture Organization of the United Nations. http://www.fao.org/faostat/en/\#home.

[5] Nguyen, N. V., Ferrero, A. (2006). Meeting the challenges of global rice production. Paddy Water Environ, 4, 1-9. http://dx.doi.org/ 10.1007/s10333005-0031-5

[6] Nikitin, V.M., Obolenskaya, A.V., Schegolev, V. P. (1978). [Chemistry of wood and cellulose]. Moskow, USSR: Lesnaya promyishlennost (in Russian).

[7] Hrydnieva, T.V., Kravchenko, A.V., Barskyi, V.D., Riabyk, P.V. (2016) [Production of high purity amorphous silica from rice husk]. Visnyk NTU KhPI Bulletin of NTU KhPI Ser. Chem., Chem.Eng, (35/1207), 55-63. (in Russian)

[8] Hrydnieva, T. V., Belaia, A. A, Soroka, P. I. Tertyshnyi, O. A., Volkova, S. A. (2011) [Determination of technological parameters of the process for obtaining silicon-containing compounds from rice waste]. Zbirnyk naukovykh prats ONAKhT. - Digest scien. works ONAKhT, (39/2), 33-36. (in Russian).

[9] Gridneva, T. V., Kravchenko, A. V., Barsky, V. D., Gurevina, N.A. (2016). Obtaining of high purity amorphous silicon dioxide from rice husk. Chem. and Chem. Techn. 10(4), 499-505. http//dx.doi.org/10.23939/chcht10.04.499

[10] Gordienko, M. A. (2015). [On the yield of gasification products of solid carbon-containing raw materials]. Uglehimicheskiy zhurnal - The Coal- Chemical Journal, (1-2), 21-25. (in Russian).

[11] Fernandes, I. J., Calheiro, D., Sanches, F.A. L., Camacho, Al. La. D., Rocha, T. L. A de C., Moraes, C. Al. M., Sousa, V. C. (2017). Characterization of silica produced from rice husk ash: Comparison of 
purification and processing methods. Mater. Resear., 20(2), 512-518. http//dx.doi.org/10.1590/19805375-MR-2016-1043

[12] Tertyshnyi, O. A., Ovcharov, V. I., Sukhyy, K. M., Sokolova, L. A., Kalinyuk, V. L. (2018). The use of the heat-treated rise husk as elastomeric compositions fillers. Voprosy khimii i khimicheskoi technologii - Issues of Chemistry and Chemical Technology, (3), 79-89 (in Russian).

[13] Dizaji, H. B., Zeng, T., Hartmann, I., Enke, D., Schliermann, T., Lenz, V., Bidabadi, M. (2019). Generation of high quality biogenic silica by combustion of rice husk and rice straw combined with pre- and post-treatment strategies-a review. Apll. Sci., 9 (1083), 1-27. http//dx.doi.org/10.3390/app9061083

[14] Costa, J. A. S., Paranhos, C. M. (2018). Systematic evaluation of amorphous silica production from rice husk ashes. J Clean Prod., 192, 688-697. http//dx.doi.org/10.1016/j.clipro. 2018.05.028

[15] Tolba, G M. K., Bastaweesy, A. M, Ashour, E. A., Abdelmoez, W., Khalil, K. A., Barakat, N. A. M. (2016). Effective and highly recyclable ceramic membrane based on amorphous nanosilica for dye removal from the aqueous solutions. Arab. J. Chem., 9, 286-296. http//dx.doi.org/10.1016/j.arabje.2015.05.009

[16] Hossain, Sk S., Mathur, L., Roy, P. K. (2018). Rice husk/rice husk ash as an alternative source of silica in ceramics: A review. J. As. Cer. S., 6(4), 299-313. http//dx.doi.org/10.1080/21870764.2018.1539210

[17] Kalapathy, U., Proctor, A., Shultz, J. (2000). A simple method for production of pure silica from rice hull ash. Bioresource Tech., 73, 257-262.

https://www.researchgate.net/publication/22256771 $\underline{4}$

[18] Todkar, B.S., Deorukhkar, On. A., Deshmukh, Sat. M. (2016). Extraction of silica from rice husk. International. Journal of Engineering Research and Development, 12(3), 69-74.

[19] Yuvakkumar, R., Elango, V., Rajendran, V., Kannan, N. (2014) High-purity nano silica powder from rice husk using a simple chemical method. Journal of Experimental Nanoscience, 9(3) 272-281. http://dx.doi.org/10.1080/17458080.2012.656709
[20] Liou, T.-H. (2004). Preparation and characterization of nano-structured silica from rice husk. Materials Science and Engineering, A364, 313-323. http://dx.doi.org/ 10.1016/ j.msea. 2003.08.045

[21] Bakara, R. Abu., Yahyaa, R., Gana, S. N. (2016) Production of high purity amorphous silica from rice husk. Procedia Chemistry, 19, 189 - 195. http://dx.doi.org/10.1016/j.proche.2016.03.092

[22] Real, C., Alcala, Maria D., Criado, Jose M. (1996). Preparation of silica from rice husks. J. Am. Ceram. Soc., 79(8) 2012-2016.

[23] Gu, S., Zhou, J., Luo, Z., Wang, Q., Shi, Z. (2015). Kinetic study on the preparation of silica from rice husk under various pretreatments. J Therm Anal Calorim., 119, 2159-2169. http//dx.doi.org/10.1007/s10973-0144219-z

[24] Hrydnieva, T.V., Soroka, P.I., Tertyshnyi, O.A., Smirnova, H.S., Riabyk, P.V. (2007). [Investigation of the lignin extraction process with an alcohol extractant]. Voprosy khimii i khimicheskoi technologii - Issues of Chemistry and Chemical Technology, (6), 212-214. (in Russian).

[25] Uendland, U. (1978). [Thermal Analysis Methods], Moskow, USSR: Mir. (in Russian).

[26] Zako, J., Arzt, H. E. (1974). Kinetic Analysis of TG-data Thermal decomposition of calcium carbonate. Ibid., (6), 651-656.

[27] Hrydnieva, T. V., Belaia, A. A, Soroka, P. I. Tertyshnyi, O. A., Volkova, S. A. (2010). [Study of the kinetics of processes for producing silicon-containing compounds from rice husk]. Zbirnyk naukovykh prats ONAKhT. - Digest scien. works ONAKhT, 2(37), 4-8. (in Russian).

[28] Bogolitsin, K. H., Lunin, V. V. (2010). [Physical chemistry of lignin]. Moskow, Russian Federation: Akademkniga. (in Russian).

[29] Neish, A. C. (1965) Coumarins, phenylpropanes and lignin. Plant biochemistry In J. Bonner, J. E. Varner (Eds.). New York, USA: Academic Press.

[30] Sestak, J., Satavo, V., Wendlandt, W.W. (1973). The studies of heterogeneous processes by thermal analysis. Thermochim. acta., 7(5), 333-356.

[31] Parhomenko, V. D., Soroka, P. I., Golubkov, L. A., Lipatov, P. V. (1988). [Obtaining ferrite powders in the flows of high-temperature coolants]. Kiev, USSR: Nauk. dumka. (in Russian). 